\title{
Design and Application of Nucleic Acid Standards for Quantitative Detection of Enteric Viruses by Real-Time PCR
}

\author{
Mónica Martínez-Martínez • Marta Diez-Valcarce • \\ Marta Hernández · David Rodríguez-Lázaro
}

Received: 5 April 2011/Accepted: 11 May 2011/Published online: 21 May 2011

(C) The Author(s) 2011. This article is published with open access at Springerlink.com

\begin{abstract}
Synthetic multiple-target RNA and DNA oligonucleotides were constructed for use as quantification standards for nucleic acid amplification assays for human norovirus genogroup I and II, hepatitis E virus, murine norovirus, human adenovirus, porcine adenovirus and bovine polyomavirus. This approach overcomes the problems related to the difficulty of obtaining practical quantities of viral RNA and DNA from these viruses. The quantification capacity of assays using the standards was excellent in each case $\left(R^{2}>0.998\right.$ and PCR efficiency $>0.89$ ). The copy numbers of the standards were equivalent to the genome equivalents of representative viruses (murine norovirus and human adenovirus), ensuring an accurate determination of virus presence. The availability of these standards should facilitate the implementation of nucleic acid amplification-based methods for quantitative virus detection.
\end{abstract}

Keywords Foodborne virus - Quantification · Nucleic acid standard $\cdot$ RT real-time PCR

Mónica Martínez-Martínez and Marta Diez-Valcarce have contributed equally this work.

M. Martínez-Martínez · M. Diez-Valcarce · M. Hernández ( $₫)$

Molecular Biology and Microbiology Laboratory, Junta de Castilla y León, Instituto Tecnológico Agrario de Castilla y León (ITACyL), Ctra. Burgos, km, 119, 47071 Valladolid, Spain e-mail: ita-herperma@itacyl.es

D. Rodríguez-Lázaro ( $\square)$

Food Safety and Technology Research Group, Junta de Castilla y León, Instituto Tecnológico Agrario de Castilla y León (ITACyL), Carretera de Burgos, km. 119, 47071 Valladolid, Spain

e-mail: ita-rodlazda@itacyl.es

\section{Introduction}

Molecular-based methods have become the gold standard for routine detection of viruses in food and environmental samples (Bosch et al. 2011; Croci et al. 2008). A realistic risk assessment strategy to assess the risks created by the contamination of food and the environment by enteric viruses will require a quantitative focus, and therefore accurate virus quantification is necessary. When a nucleic acid amplification-based method is applied for quantitative purposes, known concentrations of nucleic acids are used to construct calibration curves for quantification (Rodríguez-Lázaro et al. 2007). According to the Minimum Information for Publication of Quantitative Real-Time PCR Experiments (MIQE) guidelines (Bustin et al. 2009), nucleic acids used as standards for quantification can be of several types: purified synthetic RNA or DNA oligonucleotides spanning the complete PCR amplicon, plasmid DNA constructs, cDNA cloned into a plasmid, in vitro transcribed RNA, reference DNA pools and RNA or DNA from biological samples. However, important enteric pathogenic viruses such as human norovirus (hNoV) or hepatitis E virus (HEV) are not culturable in the laboratory (Lees and CEN WG6 TAG4 2010) and therefore, a source of viral nucleic acids necessary to make standard solutions can be very restricted, thus being more convenient to use a synthetic nucleic acid.

The application of synthetic nucleic acid molecules as standards for detection and quantification of organisms whose availability is scarce has been already applied successfully to a wide spectrum of organisms such as genetically modified plants (Hernández et al. 2005; Kuribara et al. 2002; Taverniers et al. 2004) and some pathogenic viruses (Kwiatek et al. 2010; Vester et al. 2010; Workenhe et al. 2008). A similar approach has not been followed for 
quantitative detection of non-culturable enteric viruses such as hNoV or HEV. However, as the public health implications of their presence in foodstuffs and the environment is becoming increasingly recognised (Anonymous 2008), and methods suitable for their routine monitoring are becoming available (Lees and CEN WG6 TAG4 2010), the availability of specific nucleic acid amplification standards is becoming necessary.

In the present work, we describe the construction of plasmids containing multiple-target sequences, which can be used as standards for quantification of enteric viruses (HEV, hNoV genogroups I and II, bovine polyomavirusBPyV, human adenovirus- $\mathrm{HAdV}$ and porcine adenovirusPAdV) by (reverse transcription) real-time PCR. The performance in quantitative reactions of these synthetic standards was assessed in comparison to natural nucleic acids extracted from viruses.

\section{Materials and Methods}

\section{Viruses and Cell Cultures}

Murine norovirus 1 (MNV-1) was propagated in RAW264.7 cells, and titrated by end-point dilution (final stock concentration $4.22 \times 10^{6}$ median tissue culture infective dose $\left(\mathrm{TCID}_{50}\right) \mathrm{ml}^{-1}$ ). Human adenovirus type-2 (HAdV-2) was propagated in A549 cells and titrated by the same technique (final stock concentration $2.1 \times 10^{7}$ TCID $_{50} \mathrm{ml}^{-1}$ ). Total viral RNA or DNA was extracted from infected cultures using QIAamp viral RNA mini kit (QIAGEN, GMBH, Inc., Hilden, Germany), following manufacturer's instructions. MNV-1 was supplied by Prof. Herbert W. Virgin IV, Washington University School of Medicine, US according to the MTA signed within the EU project VITAL, and HAdV-2 was supplied by Prof. Rosina Girones, University of Barcelona, Spain.

Construction of a Plasmid for Transcription of Synthetic RNA

A synthetic DNA molecule was designed to contain target sequences for reverse transcription real-time PCR (RTqPCR) assays for HEV (Jothikumar et al. 2006), hNoV GI (Svraka et al. 2007) and hNoV GII (da Silva et al. 2007). The oligonucleotide was synthesised (Eurofins MWG Operon, Ebersberg, Germany) and cloned into a pCR 2.1TOPO plasmid (Invitrogen, Breda, The Netherlands). Then, the target sequence for a RT-qPCR assay for murine norovirus (MNV-1) (Baert et al. 2008) was added to the $3^{\prime}$ end of the plasmid. This was done by modifying the primers to add tails containing sites for XhoI (primer FwORF1/ORF2) and ApaI (primer RvORF1/ORF2). The final sequence was $424 \mathrm{bp}$ (Fig. 1). The recombinant plasmid was designated as pCR2.1TOPO-rSTD.

\section{Production of the Synthetic RNA}

Six micrograms of pCR2.1TOPO-rSTD clone were linearised by digestion with HindIII enzyme (New England Biolabs, Ipswich, MA, USA) prior to in vitro transcription. The linearised plasmid was subsequently purified using the QIAquick PCR purification kit (QIAGEN, GMBH, Inc., Hilden, Germany) and in vitro transcribed using T7 RNA
Fig. 1 Graphic representation of pCR2.1TOPO-rSTD containing the sequence of the synthetic rFBV1 RNA. The length of the plasmid pCR2.1TOPO-rSTD is 4295 bp. The viral insert was flanked by NotI and ApaI sites. The sequences of the RT-qPCR assays are shown (hNoV GIIwithin box, hNoV GI-italics, HEV—bold and MNV-1underlined. The sequences corresponding to the TOPO vector are in normal type

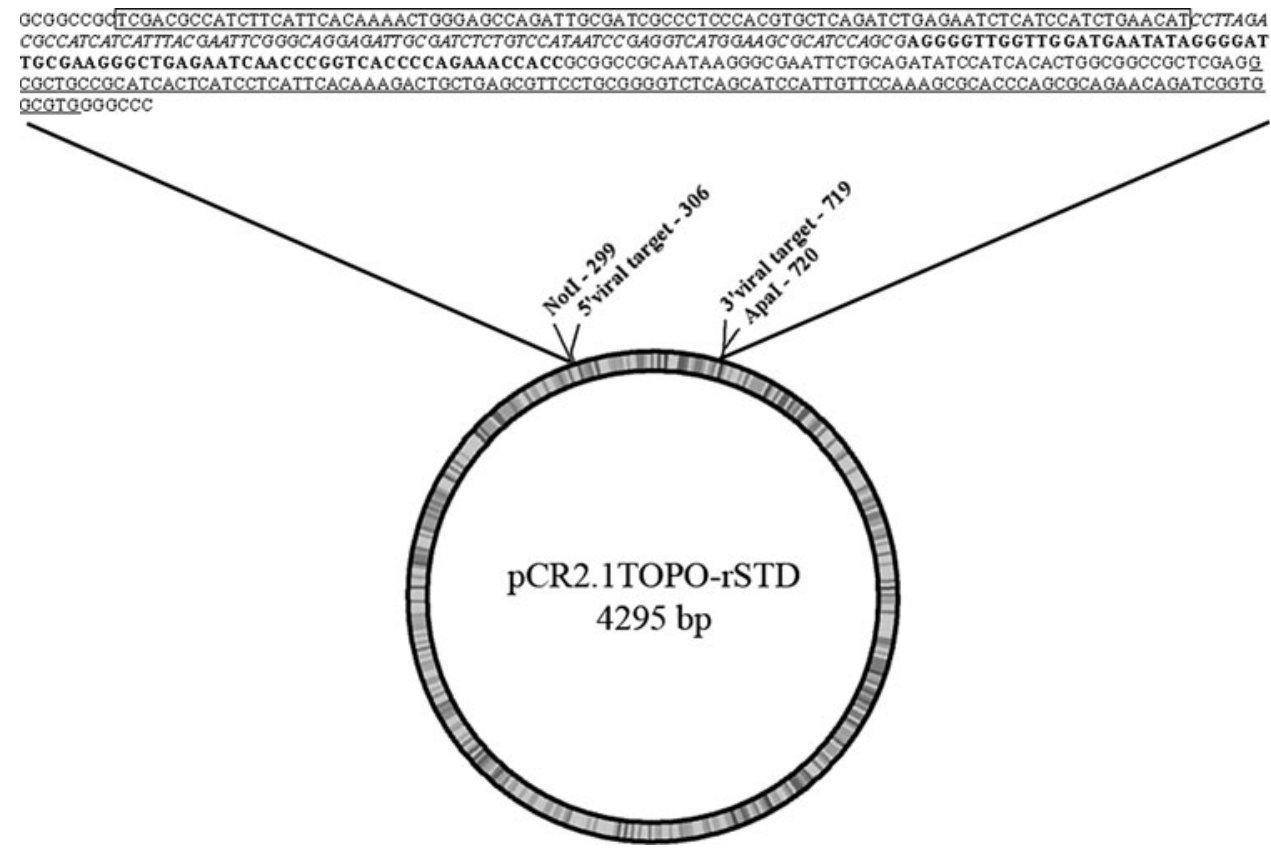


polymerase (Riboprobe in vitro transcription system, Promega, Madison, WI, USA) following the manufacturer's instructions. As viral target DNA was reverse cloned in pCR-2.1 TOPO vector, transcription was performed in the antisense direction to generate a ssRNA(+). Residual DNA was removed by digestion with $35 \mathrm{U}$ of RNase-free DNase contained in the kit. Subsequently, RNA purification was carried out using RNeasy kit (QIAGEN, GMBH, Inc., Hilden, Germany). Parallel qPCR and RT-qPCR assays for each virus verified that residual DNA had been removed (data not shown). To check the integrity of the RNA, an aliquot was electrophoresed in a native $1.5 \%$ agarose gel. To verify that the sequence of the insert was correct, direct sequencing using two pairs of flanking primers M13 Forward/M13 Reverse and FwORF1/ORF2/COG2R was performed using the kits Big Dye v3.1 or v1.1 (Applied Biosystems, Foster City, CA, USA) in an ABI3130 Genetic Analyzer (Applied Biosystems, Foster City, CA, USA) following manufacturer's instructions. Transcription reactions were repeated several times to obtain a higher amount of RNA, and after the integrity and purity was assessed, the RNA solutions were pooled, aliquoted in suitable volumes and stored at $-80^{\circ} \mathrm{C}$. The synthesised RNA molecule was designated rFBV1.

\section{Construction of the Synthetic DNA}

A synthetic DNA molecule was designed to contain target sequences for qPCR assays for BPyV (Hundesa et al. 2010), HAdV (Hernroth et al. 2002) and PAdV (Hundesa et al. 2009). The oligonucleotide was synthesised (Eurofins MWG Operon, Ebersberg, Germany) and cloned into a pCR 2.1-TOPO plasmid (Invitrogen, Breda, The Netherlands). The final sequence was 228 bp (Fig. 2). To verify that the sequence of the insert was correct, direct sequencing using the two flanking primers M13 Forward and M13 Reverse was performed as for synthetic RNA. The plasmid was cloned in E. coli, and a purified solution prepared using QIAGEN plasmid Midi kit (QIAGEN, GMBH, Inc., Hilden, Germany). The DNA solutions were pooled, aliquoted in suitable volumes and stored at $-80^{\circ} \mathrm{C}$. The synthesised DNA was designated as pFBV2.

\section{Quantification of RNA and DNA}

RNA and DNA concentrations were determined by UV spectrophotometry in a Nanodrop ND-1000 spectrophotometer (ThermoScientific, Wilmington, NC, USA). The measurements were performed in duplicate and concentration in $\mathrm{g}$ was converted to molecule number using the following formulae:

$$
\begin{aligned}
& \text { RNA molecules } \times \mu \mathrm{l}^{-1} \\
&= {[\mathrm{g} / \mu \mathrm{l}) /(\text { transcript length in nucleotides } \times 340)] } \\
& \times 6.022 \times 10^{23} \\
& \text { DNA molecules } \times \mu \mathrm{l}^{-1} \\
&= {[\mathrm{g} / \mu \mathrm{l}) /(\text { plasmid length in base pairs } \times 660)] } \\
& \times 6.022 \times 10^{23}
\end{aligned}
$$

RT-qPCRs and qPCRs

All RT-qPCRs and qPCRs were run in an LC 480 II instrument (Roche, Mannheim, Germany). For RT-qPCR assays, $5 \mu \mathrm{l}$ of the RNA solution were added to $15 \mu \mathrm{l}$ of master mix consisting of $7.4 \mu \mathrm{l}$ Light Cycler 480 Master Hydrolysis probes (Roche, Mannheim, Germany), and 1.3 $\mu \mathrm{l}$ activator $(50 \mathrm{mM})$. Primers and probes concentrations
Fig. 2 Graphic representation of $\mathrm{pFBV} 2$ containing the sequence of the synthetic DNA. The length of the plasmid is $4,159 \mathrm{bp}$. The viral insert was flanked by ApaI and NotI sites. The sequences of the qPCR assays are shown (BPyV-bold, HAdV-2-italics and PAdVunderlined. The sequences corresponding to the TOPO vector are in normal type

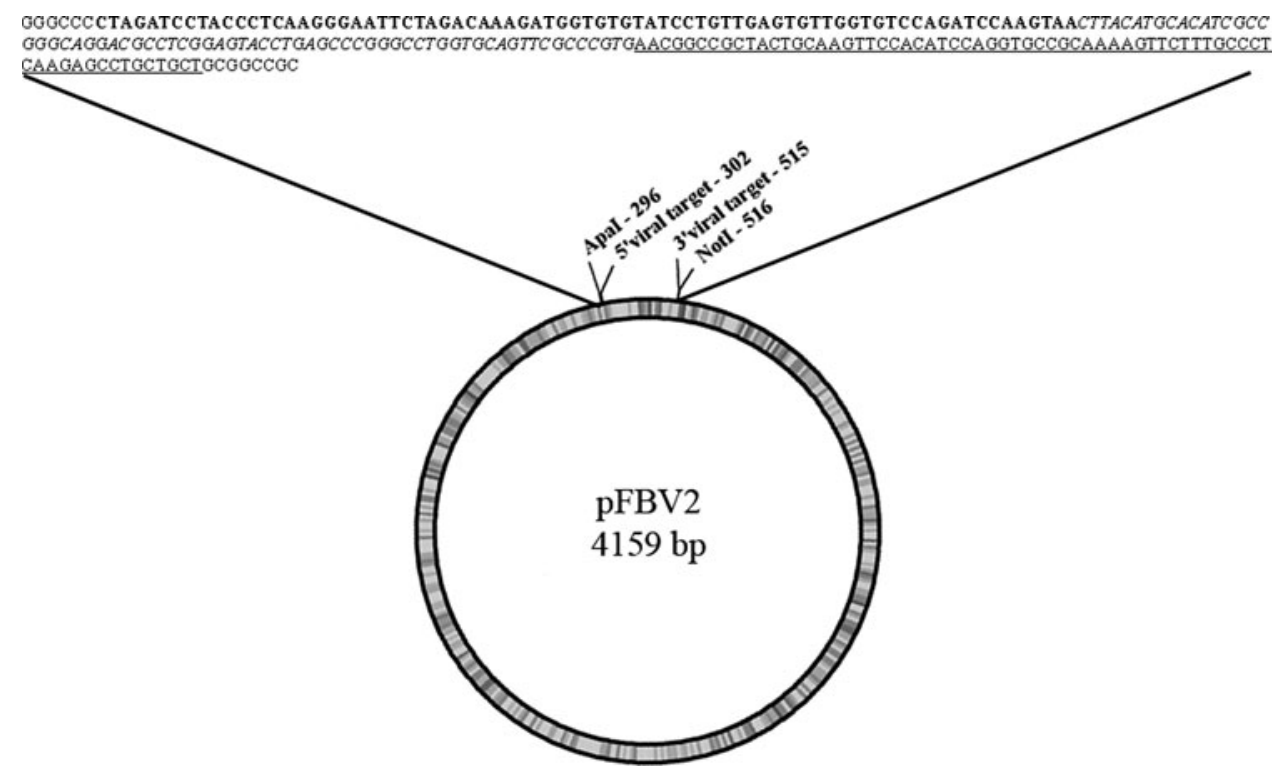


were those described before for MNV-1 (Baert et al. 2008) and HEV (Jothikumar et al. 2006). For hNoV GI and GII assays, forward primer was added at a concentration of 500 $\mathrm{nM}$, reverse primer at $900 \mathrm{nM}$ and probe at $250 \mathrm{nM}$. Cycling conditions consisted of $63^{\circ} \mathrm{C}$ for $30 \mathrm{~min}$ followed by denaturation at $95^{\circ} \mathrm{C}$ for $5 \mathrm{~min}$, and 45 cycles of denaturation at $95^{\circ} \mathrm{C}$ for $15 \mathrm{~s}$, and annealing, amplification and detection at $60^{\circ} \mathrm{C}$ for $1 \mathrm{~min}$. For HEV, cycling conditions were $63^{\circ} \mathrm{C}$ for $30 \mathrm{~min}$ followed by denaturation at $95^{\circ} \mathrm{C}$ for $5 \mathrm{~min} 45$ cycles of $10 \mathrm{~s}$ at $95^{\circ} \mathrm{C}$, annealing at $55^{\circ} \mathrm{C}$ for $20 \mathrm{~s}$ and amplification and detection at $72^{\circ} \mathrm{C}$ for $15 \mathrm{~s}$. For MNV-1, cycling conditions were $63^{\circ} \mathrm{C}$ for $30 \mathrm{~min}$ followed by denaturation at $95^{\circ} \mathrm{C}$ for $5 \mathrm{~min}$ and 40 cycles of denaturation at $95^{\circ} \mathrm{C}$ for $15 \mathrm{~s}$ and annealing, amplification and detection at $60^{\circ} \mathrm{C}$ for $1 \mathrm{~min}$.

For qPCR assays, $5 \mu \mathrm{l}$ of the DNA solution were added to $20 \mu \mathrm{l}$ of master mix consisting of $12.5 \mu \mathrm{l}$ Light Cycler 480 Probes Master (Roche, Mannheim, Germany). Primers and probes concentrations were those described previously (Hernroth et al. 2002; Hundesa et al. 2010; Hundesa et al. 2009). Cycling conditions for HAdV and PAdV assays consisted of denaturation at $95^{\circ} \mathrm{C}$ for $10 \mathrm{~min}$, and 45 cycles of denaturation at $95^{\circ} \mathrm{C}$ for $15 \mathrm{~s}$, and annealing, amplification and detection at $60^{\circ} \mathrm{C}$ for $1 \mathrm{~min}$. Cycling conditions for $\mathrm{BPyV}$ were denaturation at $95^{\circ} \mathrm{C}$ for $10 \mathrm{~min}$ followed by 45 cycles of denaturation at $95^{\circ} \mathrm{C}$ for $15 \mathrm{~s}$, annealing at $60^{\circ} \mathrm{C}$ for $1 \mathrm{~min}$.

\section{Results}

Evaluation of the Performance of the RT-qPCR Assays Using Synthesised RNA

The results of the performance of the four RT-qPCR assays (hNoVGI, hNoVGII, HEV and MNV-1) using tenfold dilutions (from $10^{6}$ to $10^{1}$ RNA molecules) of the rFVB1 are shown in Table 1 . The capacity for quantification using rFVB1 for each RT-qPCR assay was also calculated based on the linearity and PCR efficiency $(E)$ (Rodríguez-Lazaro et al. 2005). Both parameters were very close to the optimal in all RT-qPCR assays $\left(R^{2} \geq 0.998\right.$ and $E \geq 0.89$; Table 1) demonstrating that the use of the synthetic RNA for constructing standard quantification curves is an excellent approach. The limits of quantification (LOQ) were $1 \times 10^{1} \mathrm{rFVB} 1$ copies per reaction in all the assays, with the exception of hNoV GII and HEV where the LOQ was $1 \times 10^{2}$ copies per reaction (Table 1 ). In addition, reliable quantification was possible over a dynamic range at least of five logs.

The performance of the RT-qPCR assays using tenfold dilutions of rFVB1 were also compared to those assays using tenfold dilutions of native RNA from MNV-1 extracted from infected cells (from $10^{6}$ to $10^{1}$ RNA molecules). The performances were very similar, as the linearity and PCR efficiency values were very similar $\left(R^{2}\right.$ of

Table 1 Quantitative detection of synthetic (hNoVGI, hNoVGII, HEV and MNV-1) and native MNV-1 RNA

\begin{tabular}{|c|c|c|c|c|c|}
\hline \multirow[t]{2}{*}{ Approx. molecules/reaction ${ }^{\mathrm{a}}$} & \multicolumn{4}{|l|}{ Synthetic RNA } & \multirow{2}{*}{$\begin{array}{l}\text { Virus RNA } \\
{\mathrm{MNV}-1^{\mathrm{f}}}^{C_{\mathrm{p}} \text { value }^{\mathrm{g}}}\end{array}$} \\
\hline & $\begin{array}{l}\text { hNoVGI } \\
C_{\mathrm{p}} \text { value }^{\mathrm{g}}\end{array}$ & $\begin{array}{l}\mathrm{hNoVGII} \\
C_{\mathrm{p}} \text { value }\end{array}$ & $\begin{array}{l}\mathrm{HEV}^{\mathrm{d}} \\
C_{\mathrm{p}} \text { value }\end{array}$ & $\begin{array}{l}\mathrm{MNV}-1^{\mathrm{e}} \\
C_{\mathrm{p}} \text { value }^{\mathrm{g}}\end{array}$ & \\
\hline $1 \times 10^{6}$ & $14.75 \pm 0.24$ & $12.45 \pm 0.07$ & $16.61 \pm 0.18$ & $15.57 \pm 0.04$ & $15.59 \pm 0.02$ \\
\hline $1 \times 10^{5}$ & $17.91 \pm 0.15$ & $15.89 \pm 0.07$ & $19.80 \pm 0.15$ & $19.56 \pm 0.04$ & $19.32 \pm 0.04$ \\
\hline $1 \times 10^{4}$ & $21.68 \pm 0.30$ & $19.35 \pm 0.13$ & $23.35 \pm 0.16$ & $23.30 \pm 0.04$ & $22.95 \pm 0.03$ \\
\hline $1 \times 10^{3}$ & $25.01 \pm 0.28$ & $23.11 \pm 0.15$ & $26.71 \pm 0.21$ & $27.07 \pm 0.05$ & $26.65 \pm 0.02$ \\
\hline $1 \times 10^{2}$ & $28.47 \pm 0.37$ & $26.92 \pm 0.20$ & $29.54 \pm 0.30$ & $30.30 \pm 0.03$ & $29.85 \pm 0.01$ \\
\hline $1 \times 10^{1}$ & $32.23 \pm 0.45$ & $35.56 \pm 0.25$ & $\mathrm{nd}^{\mathrm{h}}$ & $33.74 \pm 0.04$ & $33.09 \pm 0.03$ \\
\hline
\end{tabular}

${ }^{a}$ Estimated number of synthetic rFBV1 or virus RNA molecules in each RT-qPCR run

${ }^{\mathrm{b}}$ hNoVGI RT-qPCR results from tenfold serial dilutions of synthetic RNA rFBV1. The standard curve was: $y=-3.497 x+35.58$; and the $R^{2}$ and PCR efficiency values were 0.999 and 0.93 , respectively

${ }^{\mathrm{c}}$ hNoVGII RT-qPCR results from tenfold serial dilutions of synthetic RNA rFBV1. The standard curve was: $y=-3.616 x+34.00$; and the $R^{2}$ and PCR efficiency values were 0.999 and 0.89 , respectively

${ }^{\mathrm{d}}$ HEV RT-qPCR results from tenfold serial dilutions of synthetic RNA rFBV1. The standard curve was: $y=-3.277 x+36.31$; and the $R^{2}$ and PCR efficiency values were 0.998 and 1.02 , respectively

e MNV-1 RT-qPCR results from tenfold serial dilutions of synthetic RNA rFBV1. The standard curve was: $y=-3.624 x+37.60$; and the $R^{2}$ and PCR efficiency values were 0.998 and 0.89 , respectively

${ }^{\mathrm{f}}$ MNV-1 RT-qPCR results from tenfold serial dilutions of RNA purified from MNV-1. The standard curve was: $y=-3.508 x+36.85$; and the $R^{2}$ and PCR efficiency values were 0.998 and 0.93 , respectively

g Cycle number at which fluorescence intensity equals a fixed threshold. Mean value \pm standard error of the mean. The experimental results were statistically significant $(P<0.05)$ taking into account unavoidable error associated with serial dilutions

h Not detected 
0.998 and $E$ of 0.93 and 0.89 for native and synthetic MNV-1 RNA, respectively) (Table 1; Fig. 3a). When the $C_{\mathrm{p}}$ (cycle to positivity) values obtained using each type of RNA were plotted in a graphic (synthetic RNA $C_{\mathrm{p}}$ values vs. MNV-1 RNA $C_{\mathrm{p}}$ values) an excellent correlation (slope of 0.967 and $R^{2}$ of 0.999 ) was found (Fig. 3b).

Evaluation of the Performance of the qPCR Assays Using Synthetic DNA

The results of the performance of the three qPCR assays (BPyV, PAdV and HAdV) using tenfold dilutions (from $10^{5}$ to $10^{1}$ DNA molecules) of the pFBV2 are shown in Table 2. Similarly to the RT-qPCR assays, the capacity for quantification was also calculated based on the linearity and PCR efficiency. Both parameters were very close to the optimal in all qPCR assays $\left(R^{2} \geq 0.96\right.$ and $E \geq 0.997$; Table 2) demonstrating that the use of the synthetic DNA for constructing standard quantification curves is an excellent approach. The limits of quantification (LOQ) were $1 \times 10^{1} \mathrm{pFBV} 2$ copies per reaction in all the assays (Table 2). In addition, reliable quantification was possible over a dynamic range at least of five logs.

The performance of the qPCR assays using tenfold dilutions of pFBV2 were also compared to those assays using tenfold dilutions of native DNA from HAdV-2 extracted from infected cells (from $10^{5}$ to $10^{1}$ DNA molecules). The performances were very similar, as the linearity and PCR efficiency values were very similar $\left(R^{2}\right.$ of 0.999 and $E$ of 1.00 and 0.96 for native and synthetic HAdV-2 DNA, respectively) (Table 2; Fig. 4a). When the $C_{\mathrm{p}}$ values obtained using each type of DNA were plotted in a graphic (synthetic DNA $C_{\mathrm{p}}$ values vs. HAdV-2 DNA $C_{\mathrm{p}}$

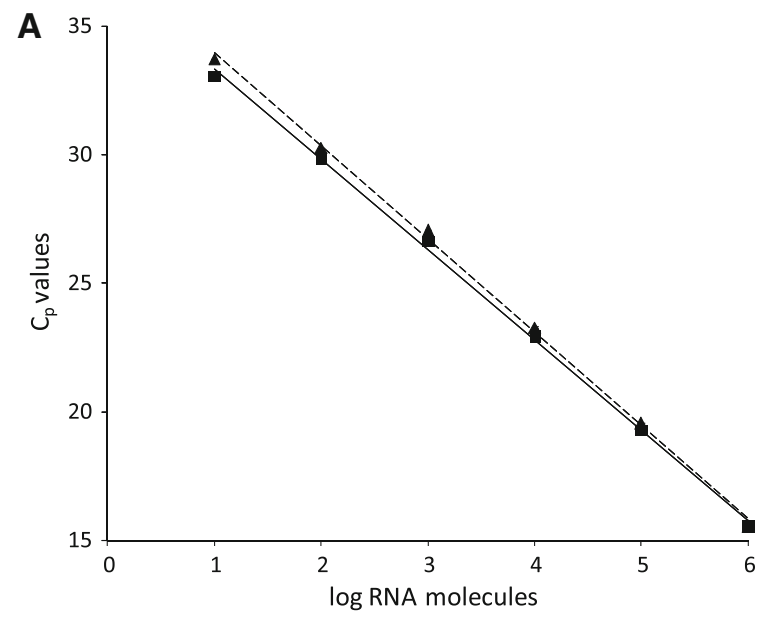

Fig. 3 Comparison of the performance of the RT-qPCR assays using native and synthetic RNA. a Standard curve generated by tenfold dilutions (from $10^{6}$ to $10^{1}$ RNA molecules) of rFVB1 (triangle) and values) an excellent correlation (slope of the curve of 0.965 and $R^{2}$ value of 0.999 ) was found (Fig. 4b).

\section{Discussion}

Accurate quantification of viruses is important to determine not only the level of contamination of food, surfaces, waters, etc., but also to determine any reduction of virus contamination after disinfection treatments. It can also be used to determine a possible linkage of virus levels to risk of infection or outbreaks (Lees and CEN WG6 TAG4 2010). Probably because of the difficulty of obtaining suitable RNA, several previously published methods have used DNA containing virus-complementary sequences as quantification standards. However, this approach is far from optimal, as the reverse transcription step is thus not considered (Boeuf et al. 2005; Terlizzi et al. 2010; Vester et al. 2010; Workenhe et al. 2008).

Absolute quantification will be reliable only if the standard and the unknown samples are retrotranscribed (only for RNA molecules) and amplified with the same efficiency (Boeuf et al. 2005). So standard curves obtained after amplification of tenfold serial dilutions of purified viral RNA or DNA and external RNA or DNA standards were compared (Tables 1, 2; Figs. 1, 2). RNA transcribed from linearised plasmid pCR2.1TOPO-rSTD was found to give more reliable viral RNA copy number estimation than RNA transcribed from circular pCR2.1TOPO-rSTD (data not shown). It has been suggested that an acceptable RT-qPCR standard curve should have a correlation coefficient $\left(R^{2}\right) \geq 0.98$ and a slope value $(s)$ between 3.6 and 3.1, corresponding to reaction efficiencies $(E)$ between 0.9

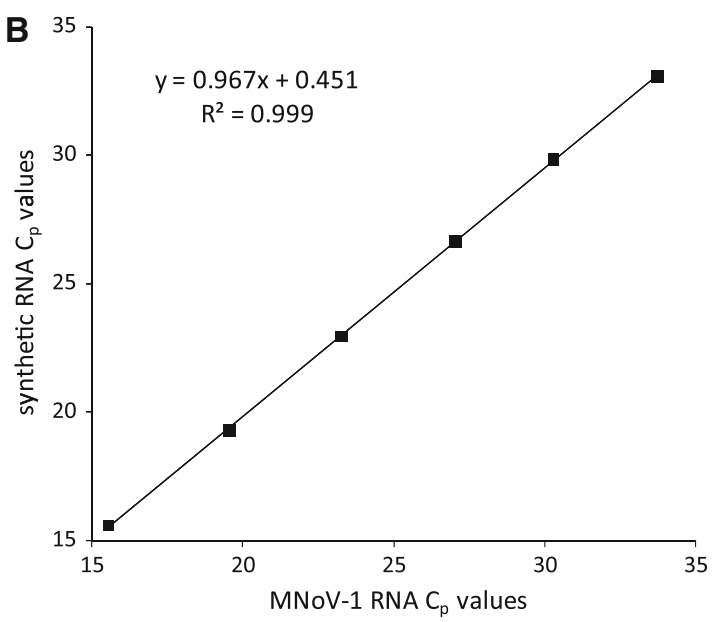

native RNA from MNV-1 extracted from infected cells (square). b Representation of the equivalence of the $C_{\mathrm{p}}$ values of tenfold dilutions (from $10^{6}$ to $10^{1}$ RNA molecules) of $\mathrm{rFVB} 1$ ( $y$-axis) and MNV-1 ( $x$-axis) 
Table 2 Quantitative detection of synthetic (PAdV, BPyV and HAdV) and native HAdV DNA

\begin{tabular}{|c|c|c|c|c|}
\hline \multirow[t]{2}{*}{ Approx. molecules/reaction ${ }^{\mathrm{a}}$} & \multicolumn{3}{|l|}{ Synthetic DNA } & \multirow{2}{*}{$\begin{array}{l}\text { Virus DNA } \\
\text { HAdV }^{\mathrm{e}} \\
C_{\mathrm{p}} \text { value }^{\mathrm{f}}\end{array}$} \\
\hline & $\begin{array}{l}\mathrm{PAdV}^{\mathrm{b}} \\
C_{\mathrm{p}} \text { value }^{\mathrm{f}}\end{array}$ & $\begin{array}{l}\mathrm{BPyV}^{\mathrm{c}} \\
C_{\mathrm{p}} \text { value }^{\mathrm{f}}\end{array}$ & $\begin{array}{l}\mathrm{HAdV}^{\mathrm{d}} \\
C_{\mathrm{p}} \text { value }^{\mathrm{f}}\end{array}$ & \\
\hline $1 \times 10^{5}$ & $22.46 \pm 0.10$ & $23.96 \pm 0.07$ & $22.08 \pm 0.04$ & $22.15 \pm 0.02$ \\
\hline $1 \times 10^{4}$ & $25.83 \pm 0.13$ & $27.61 \pm 0.12$ & $25.49 \pm 0.04$ & $25.49 \pm 0.04$ \\
\hline $1 \times 10^{3}$ & $29.29 \pm 0.11$ & $30.98 \pm 0.12$ & $28.84 \pm 0.05$ & $28.92 \pm 0.03$ \\
\hline $1 \times 10^{2}$ & $32.32 \pm 0.07$ & $34.23 \pm 0.04$ & $32.11 \pm 0.05$ & $32.06 \pm 0.02$ \\
\hline $1 \times 10^{1}$ & $35.95 \pm 0.09$ & $36.81 \pm 0.23$ & $35.92 \pm 0.10$ & $35.44 \pm 0.06$ \\
\hline
\end{tabular}

${ }^{a}$ Estimated number synthetic pFBV2 or virus DNA molecules in each qPCR run

b PAdV qPCR results from tenfold serial dilutions of synthetic DNA pFBV2. The standard curve was: $y=-3.347 x+42.55$; and the $R^{2}$ and PCR efficiency values were 0.999 and 0.99 , respectively

${ }^{\mathrm{c}}$ BPyV qPCR results from tenfold serial dilutions of DNA pFBV2. The standard curve was: $y=-3.232 x+43.64$; and the $R^{2}$ and PCR efficiency values were 0.999 and 1.04 , respectively

${ }^{\mathrm{d}}$ HAdV qPCR results from tenfold serial dilutions of DNA pFBV2. The standard curve was: $y=-3.430 x+42.60$; and the $R^{2}$ and PCR efficiency values were 0.999 and 1.02 , respectively

${ }^{\text {e }}$ HAdV qPCR results from tenfold serial dilutions of DNA purified from HAdV-2. The standard curve was: $y=-3.315 x+42.07$; and the $R^{2}$ and PCR efficiency values were 0.999 and 1.00 , respectively

${ }^{\mathrm{f}}$ Cycle number at which fluorescence intensity equals a fixed threshold (Rodríguez-Lázaro et al. 2003). Mean value \pm standard error of the mean. The experimental results were statistically significant $(P<0.05)$ taking into account unavoidable error associated with serial dilutions

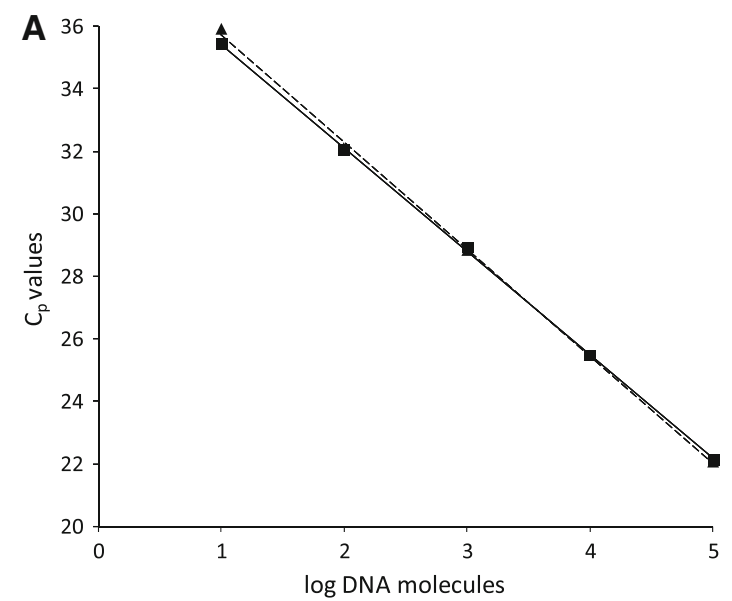

Fig. 4 Comparison of the performance of the qPCR assays using native and synthetic DNA. a Standard curve generated by tenfold dilutions (from $10^{6}$ to $10^{1}$ DNA molecules) of pFVB2 (triangle) and native DNA from HAdV-2 extracted from infected cells (square).

and 1.1 (La Rosa et al. 2010). For rFBV1 and pFBV2 standards, all $R^{2}$ and $E$ values conformed to these acceptable limits. Any observed differences in the capacity for quantification of the individual assays using the standards were slight, and can be attributed to the effect of variations in the individual nucleic acid sequences (Boeuf et al. 2005).

The quantification of the DNA viruses was more efficient than the quantification of the RNA viruses (Tables 1,2). This is probably due to the nature of RNA, and also to the additional RT step, as its efficiency depends on many factors (Levesque-Sergerie et al. 2007). Finally, and most

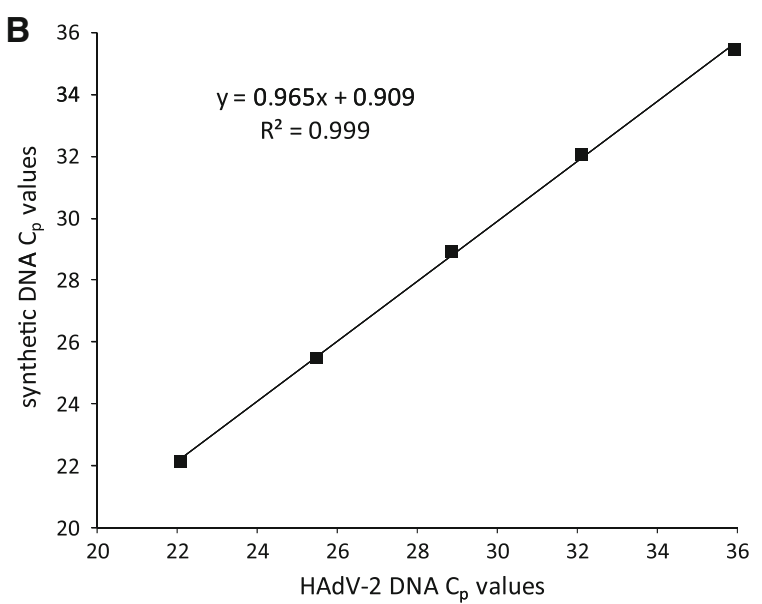

b Representation of the equivalence of the $C_{\mathrm{p}}$ values of tenfold dilutions (from $10^{6}$ to $10^{1}$ DNA molecules) of pFVB2 ( $y$-axis) and HAdV-2 ( $x$-axis)

importantly, the copy numbers of rFBV1 are equivalent to the genome equivalents of MNV-1, and the copy numbers of pFBV2 are equivalent to the genome equivalents of HAdV-2. This relationship is confidently expected to pertain also to the other virus species presented in these standards. Thus, when using these standards in monitoring a food or environmental matrix for the viruses, the analyst can be confident that the determination of virus presence he/she obtains is accurate. Thus, the availability of these standards should facilitate the implementation of nucleic acid amplification-based methods for quantitative virus detection. 
Acknowledgments The research leading to these results has received funding from the European Community's Seventh Framework Programme (FP7/2007-2013) under grant agreement no. KBBE213178 (VITAL project). M.D.-V. received a Ph.D. studentship from the Instituto Nacional de Investigación y Tecnología Agraria y Alimentaria (INIA). The authors thank Dr. Nigel Cook for the critical review of the ms.

Open Access This article is distributed under the terms of the Creative Commons Attribution Noncommercial License which permits any noncommercial use, distribution, and reproduction in any medium, provided the original author(s) and source are credited.

\section{References}

Anonymous. (2008). Viruses in food: Scientific advice to support risk management activities. WHO-FAO Microbiological Risk Assessment Series No. 13. Rome. 79 pp.

Baert, L., Wobus, C. E., Van Coillie, E., Thackray, L. B., Debevere, J., \& Uyttendaele, M. (2008). Detection of murine norovirus 1 by using plaque assay, transfection assay, and real-time reverse transcription-PCR before and after heat exposure. Applied and Environmental Microbiology, 74, 543-546.

Boeuf, P., Vigan-Womas, I., Jublot, D., Loizon, S., Barale, J. C., Akanmori, B. D., et al. (2005). CyProQuant-PCR: A real time RT-PCR technique for profiling human cytokines, based on external RNA standards, readily automatable for clinical use. BMC Immunology, 6, 5.

Bosch, A., Sanchez, G., Abbaszadegan, M., Carducci, A., Guix, S., Le Guyader, F. S., et al. (2011). Analytical methods for virus detection in water and food. Food Analytical Methods, 4, 4-13.

Bustin, S. A., Benes, V., Garson, J. A., Hellemans, J., Huggett, J., Kubista, M., et al. (2009). The MIQE guidelines: minimum information for publication of quantitative real-time PCR experiments. Clinical Chemistry, 55, 611-622.

Croci, L., Dubois, E., Cook, N., de Medici, D., Schultz, A. C., China, B., et al. (2008). Current methods for extraction and concentration of enteric viruses from fresh fruit and vegetables: Towards international standards. Food Analytical Methods, 1, 73-84.

da Silva, A. K., Le Saux, J. C., Parnaudeau, S., Pommepuy, M., Elimelech, M., \& Le Guyader, F. S. (2007). Evaluation of removal of noroviruses during wastewater treatment, using realtime reverse transcription-PCR: Different behaviors of genogroups I and II. Applied and Environmental Microbiology, 73, $7891-7897$.

Hernández, M., Rodríguez-Lázaro, D., \& Ferrando, A. (2005). Current methodology for detection, identification and quantification of genetically modified organisms. Current Analytical Chemistry, 1, 203-221.

Hernroth, B. E., Conden-Hansson, A. C., Rehnstam-Holm, A. S., Girones, R., \& Allard, A. K. (2002). Environmental factors influencing human viral pathogens and their potential indicator organisms in the blue mussel, Mytilus edulis: The first Scandinavian report. Applied and Environmental Microbiology, 68, 4523-4533.

Hundesa, A., Bofill-Mas, S., de Maluquer Motes, C., RodriguezManzano, J., Bach, A., Casas, M., et al. (2010). Development of a quantitative PCR assay for the quantitation of bovine polyomavirus as a microbial source-tracking tool. Journal of Virological Methods, 163, 385-389.

Hundesa, A., de Maluquer Motes, C., Albinana-Gimenez, N., Rodriguez-Manzano, J., Bofill-Mas, S., Sunen, E., et al.
(2009). Development of a qPCR assay for the quantification of porcine adenoviruses as an MST tool for swine fecal contamination in the environment. Journal of Virological Methods, 158, 130-135.

Jothikumar, N., Cromeans, T. L., Robertson, B. H., Meng, X. J., \& Hill, V. R. (2006). A broadly reactive one-step real-time RT-PCR assay for rapid and sensitive detection of hepatitis E virus. Journal of Virological Methods, 131, 65-71.

Kuribara, H., Shindo, Y., Matsuoka, T., Takubo, K., Futo, S., Aoki, N., et al. (2002). Novel reference molecules for quantitation of genetically modified maize and soybean. Journal of $A O A C$ International, 85, 1077-1089.

Kwiatek, O., Keita, D., Gil, P., Fernandez-Pinero, J., Jimenez Clavero, M. A., Albina, E., et al. (2010). Quantitative one-step real-time RT-PCR for the fast detection of the four genotypes of PPRV. Journal of Virological Methods, 165, 168-177.

La Rosa, G., Pourshaban, M., Iaconelli, M., \& Muscillo, M. (2010). Quantitative real-time PCR of enteric viruses in influent and effluent samples from wastewater treatment plants in Italy. Annali dell'Istituto Superiore di Sanita, 46, 266-273.

Lees, D., \& CEN WG6 TAG4. (2010). International standardisation of a Method for detection of human pathogenic viruses in molluscan shellfish. Food and Environmental Virology, 2, 146-155.

Levesque-Sergerie, J. P., Duquette, M., Thibault, C., Delbecchi, L., \& Bissonnette, N. (2007). Detection limits of several commercial reverse transcriptase enzymes: impact on the low- and highabundance transcript levels assessed by quantitative RT-PCR. BMC Molecular Biology, 8, 93.

Rodríguez-Lázaro, D., Hernández, M., Esteve, T., Hoorfar, J., \& Pla, M. (2003). A rapid and direct real time PCR-based method for identification of Salmonella spp. Journal of Microbiological Methods, 54, 381-390.

Rodríguez-Lázaro, D., Lombard, B., Smith, H., Rzezutka, A., D' Agostino, M., Helmuth, R., et al. (2007). Trends in analytical methodology in food safety and quality: Monitoring microorganisms and genetically modified organisms. Trends in Food Sciences and Technology, 18, 306-319.

Rodríguez-Lazaro, D., Pla, M., Scortti, M., Monzo, H. J., \& VazquezBoland, J. A. (2005). A novel real-time PCR for Listeria monocytogenes that monitors analytical performance via an internal amplification control. Applied Environmental Microbiology, 71, 9008-9012.

Svraka, S., Duizer, E., Vennema, H., de Bruin, E., van der Veer, B., Dorresteijn, B., et al. (2007). Etiological role of viruses in outbreaks of acute gastroenteritis in The Netherlands from 1994 through 2005. Journal of Clinical Microbiology, 45, 1389-1394.

Taverniers, I., Van Bockstaele, E., \& De Loose, M. (2004). Cloned plasmid DNA fragments as calibrators for controlling GMOs: different real-time duplex quantitative PCR methods. Analytical and Bioanalytical Chemistry, 378, 1198-1207.

Terlizzi, M. E., Bergallo, M., Astegiano, S., Sidoti, F., Gambarino, S., Solidoro, P., Costa, C., et al. (2010). Improvement of HRV quantification using cRNA-based standards for real time RTPCR. Molecular Biotechnology. doi:10.1007/s12033-010-9343-9.

Vester, D., Lagoda, A., Hoffmann, D., Seitz, C., Heldt, S., Bettenbrock, K., et al. (2010). Real-time RT-qPCR assay for the analysis of human influenza A virus transcription and replication dynamics. Journal of Virological Methods, 168, 63-71.

Workenhe, S. T., Kibenge, M. J., Iwamoto, T., \& Kibenge, F. S. (2008). Absolute quantitation of infectious salmon anaemia virus using different real-time reverse transcription PCR chemistries. Journal of Virological Methods, 154, 128-134. 